\title{
FAKTOR-FAKTOR YANG MEMENGARUHI KEPUASAN KERJA di PT. INDOHOTAMA SEJATI
}

\author{
Mulyadi Wijaya Go ${ }^{1}$, Henilia Yulita ${ }^{1 *}$ \\ ${ }^{1}$ Universitas Bunda Mulia, Indonesia \\ *e-mail: hyulita@bundamulia.ac.id
}

\begin{abstract}
Abstrak
Penelitian ini dilakukan untuk mengetahui pengaruh variabel independen yaitu Akuisisi Pengetahuan, Berbagi Pengetahuan, Penciptaan Pengetahuan, Kodifikasi Pengetahuan, dan Retensi Pengetahuan dengan variabel dependen yaitu Kepuasan Kerja. Penelitian ini mengambil sampel 122 karyawan PT. Indohotama Sejati. Adapun hasil dari penelitian ini adalah Akuisisi Pengetahuan berpengaruh yang posistif dan signifikan terhadap kepuasan kerja PT. Indohotama Sejati, Berbagi Pengetahuan tidak berpengaruh yang positif dan signifikan terhadap kepuasan kerja PT. Indohotama Sejati, Penciptaan Pengetahuan tidak berpengaruh yang positif dan signifikan terhadap kepuasan kerja PT. Indohotama Sejati, Kodifikasi Pengetahuan berpengaruh yang posistif dan signifikan terhadap kepuasan kerja PT. Indohotama Sejati, Retensi Pengetahuan tidak berpengaruh yang positif dan signifikan terhadap kepuasan kerja PT. Indohotama Sejati, serta terdapat pengaruh simultan Akuisisi Pengetahuan, Berbagi Pengetahuan, Penciptaan Pengetahuan, Kodifikasi Pengetahuan, dan Retensi Pengetahuan terhadap Kepuasan Kerja PT. Indohotama Sejati.
\end{abstract}

Kata Kunci: Akuisisi Pengetahuan; Penciptaan Pengetahuan; Kodifikasi Pengetahuan; Retensi Pengetahuan; Kepuasan Kerja

\section{ABSTRACT}

This research was conducted to determine the effect of independent variables, namely Knowledge Acquisition, Knowledge Sharing, Knowledge Creation, Knowledge Codification, and Knowledge Retention, with the dependent variable, namely Job Satisfaction. This study sampled 122 employees of PT. Indohotama Sejati. This study's results are Knowledge Acquisition that has a positive and significant effect on job satisfaction of PT. Indohotama Sejati, Knowledge Sharing does not have a positive and significant effect on job satisfaction of PT. Indohotama Sejati, Knowledge Creation does not have a positive and significant effect on job satisfaction of PT. Indohotama Sejati, Knowledge Codification has a positive and significant effect on job satisfaction of PT. True Indohotama, Knowledge Retention does not have a positive and significant effect on job satisfaction of PT. Indohotama Sejati, and there are simultaneous influences of Knowledge Acquisition, Knowledge Sharing, Knowledge Creation, Knowledge Codification, and Knowledge Retention of PT Job Satisfaction. Indohotama Sejati.

Keywords: Knowledge Acquisition; Knowledge Creation; Knowledge Codification; Knowledge Retention; Job Satisfaction

\section{PENDAHULUAN}

Sumber daya manusia merupakan asset yang paling penting bagi perusahaan dimana pada hakekatnya berfungsi sebagai faktor penggerak bagi setiap kegiatan di dalam perusahaan. Suatu organisasi dapat melakukan aktivitasnya untuk mencapai tujuan yang diinginkan perlu adanya sumber daya manusia yang baik, karena sumber daya manusia merupakan modal utama 
dalam merencanakan, mengorganisir, mengarahkan serta menggerakkan sumber daya lainnya yang ada dalam suatu perusahaan (Potale, 2015).

Produktivitas karyawan dalam sebuah perusahaan sangat penting, untuk mencapainya dengan optimal salah satunya dengan memperhatikan kepuasan kerja karyawan. Karyawan dapat dikatakan puas dalam bekerja apabila mereka merasa senang, nyaman terhadap pekerjaannya dan merasa bahwa pekerjaannya sebagai hobi. Seorang karyawan yang memiliki dedikasi yang tinggi berupaya memprioritaskan apa yang menjadi tugas dan tanggung jawabnya. Karyawan bahkan rela mengorbankan waktu pribadi dan lupa jam pulang kantor. Tipe karyawan ini biasanya tidak lagi memandang pekerjaan sebagai tugas, apalagi paksaan, melainkan hobi. Karyawan ini memiliki perasaan puas terhadap pekerjaan yang mereka kerjakan, mereka menyukai pekerjaan dan merasa nyaman (Adiwinata, 2014).

PT. Indohotama Sejati bergerak di bidang penjualan mesin jahit. Dimana distributor perusahaan ini berasal dari negara jepang yaitu Pegasus. Karyawan di PT. Indohotama berjumlah 122 orang, perusahaan ini saya teliti karena terjadi masalah pada kepuasan kerja di PT. Indohotama Sejati, tingkat kepuasan kerjanya rendah disebabkan karyawan yang merasa tidak nyaman dalam lingkungan kerja serta sikap acuh tak acuh yang terjadi antar sesama karyawan sehingga mempengaruhi tingkat kepuasan kerja di PT. Indohotama Sejati. Pada penelitian ini penulis ingin mengetahui apakah terdapat pengaruh antar pengetahuan yang dibagikan PT. Indohotama Sejati terhadap kepuasan kerja karyawan, karena kepuasan kerja mencerminkan tingkah laku karyawan tersebut dan apakah para karyawan benarbenar menyukai pekerjaan tersebut atau tidak. Peneliti memilih untuk membahas hal ini karena sesuai dengan fenomena yang terjadi, yaitu Indonesia berada di urutan pertama negara tempat orang-orang memiliki tingkat kepuasaan dan kebahagiaan terendah di dunia. Berdasarkan fenomena yang telah dijelaskan, maka yang tujuan utama penelitian adalah mengukur pengaruh faktor-faktor yang memengaruhi Kepuasan Kerja PT. Indohotama Sejati.

\section{METODE}

\section{Objek dan Subjek Penelitian}

Menurut Arikunto (2014) subjek penelitian merupakan tempat variabel melekat. Subjek penelitian adalah tempat dimana data untuk variabel penelitian diperoleh. Subjek penelitian ini adalah karyawan PT. Indohotama Sejati. Objek dari penelitian ini yaitu Akuisisi Pengetahuan, Berbagi Pengetahuan, Penciptaan Pengetahuan, Kodifikasi Pengetahuan, Retensi Pengetahuan, terhadap Kepuasan Kerja PT. Indohotama Sejati.

\section{Metode Pengumpulan Data}

Penelitian ini menggunakan metode penelitian kuantitatif. Penelitian kuantitatif adalah suatu penelitian yang menekankan analisisnya pada data-data numerical (angka) yang selanjutnya diolah dengan metode statistika (Sugiyono, 2014). Teknik pengumpulan data yang digunakan peneliti dalam penulisan ini yaitu kuesioner. Menurut Sugiyono (2014) kuesioner adalah metode pengumpulan data dengan memberikan pertanyaan-pertanyaan tertulis kepada responden untuk menjawab. Selanjutnya peneliti mengumpulkan data dengan metode kepustakaan, dalam hal ini menggunakan perpustakaan sebagai tempat untuk mencari dan mendapatkan informasi yang bersifat teoritis guna sebagai landasan penelitian yang kuat. Populasi dalam penelitian ini adalah seluruh karyawan di PT. Indohotama Sejati yang berjumlah 122 orang.

\section{Metode Analisis}

Dalam penelitian ini data yang digunakan diperoleh dari penelitian dengan 
melakukan penyebaran kuesioner serta menggunakan skala likert sebagai nilai dari jawaban setiap kuesioner yang diisi. Menurut (Sugiyono,2014) bahwa skala likert adalah skala pengukuran dengan 5 kategori respon, Sangat Setuju (SS), Setuju (S), Netral (N), Tidak Setuju (TS), dan Sangat Tidak Setuju (STS).

\section{HASIL DAN PEMBAHASAN}

\section{Pendidikan}

Data tingkat pendidikan kayawan di PT. Indohotama Sejati sebagian besar berpendidikan terakhir $\mathrm{S} 1$ yaitu $52 \%$.

\section{Umur}

Usia responden terlihat data umur karyawan PT. Indohotama Sejati sebagian besar responden berusia $25-34(47 \%)$.

\section{Analisis Data dan Interpretasi Uji Validitas}

Uji validitas digunakan untuk mengetahui kelayakan butir-butir dalam suatu kuesioner dalam mendefinisikan suatu variabel. Uji validitas sebaiknya dilakukan pada setiap butir kuesioner di uji validitasnya. Hasil $r$ hitung kita bandingkan dengan $r$ table dimana df $=n-2$ dengan sig $5 \%$. Jika $r$ hitung $>r$ tabel maka valid. Untuk jumlah sampel 122 , dengan $\mathrm{df}=122-2$ jadi $\mathrm{df}=120$ dan $\alpha 5 \%$ $r$ tabel adalah 0,176 .

\section{Uji validitas variabel Akuisisi} Pengetahuan

\begin{tabular}{|c|c|c|c|c|}
\hline $\begin{array}{c}\text { Scale } \\
\text { Mean if } \\
\text { Item } \\
\text { Deleted }\end{array}$ & $\begin{array}{c}\text { Scale } \\
\text { Variance if } \\
\text { Item } \\
\text { Deleted }\end{array}$ & $\begin{array}{c}\text { Corrected } \\
\text { Item- } \\
\text { Total } \\
\text { Correlatio } \\
n\end{array}$ & $\begin{array}{c}\text { Cronbach' } \\
\text { s Alpha if } \\
\text { Item } \\
\text { Deleted }\end{array}$ \\
\hline AP1 & 19.01 & 8.521 & .723 & .718 \\
AP2 & 18.66 & 9.217 & .535 & .779 \\
AP3 & 18.11 & 8.939 & .521 & .779 \\
\hline
\end{tabular}

Sumber: SPSS 22, $2018(\mathrm{n}=122)$

Tabel di atas menjelaskan hasil validitas dari variabel AP, yaitu Akuisisi Pengetahuan. Pada tabel di atas dapat dilihat dari tabel
Corrected Item-Total Correlation lebih besar dibandingkan $r$ tabel 0,176. Maka dapat disimpulkan variabel akuisisi pengetahuan valid.

\section{Uji validitas variabel berbagi pengetahuan \\ Item-Total Statistics}

\begin{tabular}{|l|r|r|r|r|}
\hline & $\begin{array}{c}\text { Scale } \\
\text { Mean if } \\
\text { Item } \\
\text { Deleted }\end{array}$ & $\begin{array}{c}\text { Scale } \\
\text { Variance } \\
\text { if Item } \\
\text { Deleted }\end{array}$ & $\begin{array}{c}\text { Cronbach's } \\
\text { Corrected } \\
\text { Item-Total } \\
\text { Correlation }\end{array}$ & $\begin{array}{c}\text { Alpha if } \\
\text { Item } \\
\text { Deleted }\end{array}$ \\
\hline BP1 & 22.19 & 10.650 & .452 & .754 \\
BP2 & 22.68 & 9.773 & .485 & .750 \\
BP3 & 22.93 & 10.806 & .430 & .758 \\
BP4 & 22.71 & 10.653 & .503 & .746 \\
BP5 & 22.43 & 9.702 & .555 & .733 \\
BP6 & 22.20 & 9.713 & .503 & .746 \\
BP7 & 23.31 & 10.216 & .566 & .733 \\
\hline
\end{tabular}

Sumber: SPSS 22, $2018(n=122)$

Tabel tersebut menjelaskan hasil validitas dari variabel BP, yaitu Berbagi Pengetahuan. Pada tabel di atas dapat dilihat dari tabel Corrected Item-Total Correlation lebih besar di bandingkan $r$ table 0,176 . Maka dapat disimpulkan variabel berbagi pengetahuan Valid.

\section{Uji validitas variabel Penciptaan Pengetahuan Item-Total Statistics}

\begin{tabular}{|l|r|r|r|r|}
\hline & $\begin{array}{c}\text { Scale } \\
\text { Mean if } \\
\text { Item } \\
\text { Deleted }\end{array}$ & $\begin{array}{c}\text { Scale } \\
\text { Variance } \\
\text { if Item } \\
\text { Deleted }\end{array}$ & $\begin{array}{c}\text { Corrected } \\
\text { Item-Total } \\
\text { Correlation }\end{array}$ & $\begin{array}{c}\text { Cronbach's } \\
\text { Alpha if } \\
\text { Item } \\
\text { Deleted }\end{array}$ \\
\hline PP1 & 20.52 & 9.442 & .546 & .752 \\
PP2 & 20.37 & 9.276 & .533 & .753 \\
PP3 & 19.99 & 9.248 & .486 & .762 \\
PP4 & 20.26 & 8.625 & .677 & .725 \\
PP5 & 20.25 & 9.195 & .536 & .752 \\
PP6 & 20.29 & 8.388 & .512 & .761 \\
PP7 & 20.61 & 9.712 & .336 & .792 \\
\hline
\end{tabular}

Sumber: SPSS 22, $2018(n=122)$

Tabel di atas menjelaskan hasil validitas dari variabel PP, yaitu Penciptaan Pengetahuan. Pada tabel di atas dapat dilihat dari tabel Corrected Item-Total Correlation lebih besar dibandingkan $r$ tabel 0,176 . Maka dapat disimpulkan variabel Penciptaan Pengetahuan Valid. 
Uji validitas variabel Kodifikasi

Pengetahuan

Item-Total Statistics

\begin{tabular}{|l|r|r|r|r|}
\hline & $\begin{array}{c}\text { Scale } \\
\text { Mean if } \\
\text { Item } \\
\text { Deleted }\end{array}$ & $\begin{array}{c}\text { Scale } \\
\text { Variance } \\
\text { if Item } \\
\text { Deleted }\end{array}$ & $\begin{array}{c}\text { Corrected } \\
\text { Item-Total } \\
\text { Correlation }\end{array}$ & $\begin{array}{c}\text { Cronbach's } \\
\text { Alpha if Item } \\
\text { Deleted }\end{array}$ \\
\hline KP1 & 14.83 & 4.028 & .754 & .667 \\
KP2 & 15.16 & 4.364 & .613 & .720 \\
KP3 & 13.91 & 4.512 & .521 & .755 \\
KP4 & 14.85 & 4.771 & .545 & .744 \\
KP5 & 14.86 & 5.625 & .360 & .794 \\
\hline
\end{tabular}

Sumber: SPSS 22, $2018(n=122)$

Tabel tersebut menjelaskan hasil validitas dari variabel KP, yaitu Kodifikasi Pengetahuan. Pada tabel di atas dapat dilihat dari tabel Corrected Item-Total Correlation lebih besar dibandingkan $r$ table 0,176 . Maka dapat disimpulkan variabel Kodifikasi Pengetahuan Valid.

\section{Uji validitas variabel RetensiPengetahuan}

\section{Item-Total Statistics}

\begin{tabular}{|c|r|r|r|r|}
\hline & $\begin{array}{c}\text { Scale } \\
\text { Mean if } \\
\text { Item } \\
\text { Deleted }\end{array}$ & $\begin{array}{c}\text { Scale } \\
\text { Variance } \\
\text { if Item } \\
\text { Deleted }\end{array}$ & $\begin{array}{c}\text { Corrected } \\
\text { Item-Total } \\
\text { Correlation }\end{array}$ & $\begin{array}{c}\text { Cronbach } \\
\text { 's Alpha if } \\
\text { Item } \\
\text { Deleted }\end{array}$ \\
\hline RP1 & 7.63 & 2.169 & .532 & .638 \\
RP2 & 7.75 & 2.005 & .476 & .722 \\
RP3 & 7.78 & 2.157 & .628 & .536 \\
\hline
\end{tabular}

Sumber: SPSS 22, $2018(n=122)$

Tabel di atas menjelaskan hasil validitas dari variabel RP, yaitu Retensi Pengetahuan. Pada tabel di atas dapat dilihat dari tabel Corrected Item-Total Correlation lebih besar dibandingkan $r$ table 0,176 . Maka dapat disimpulkan variabel Retensi Pengetahuan Valid.

Uji validitas variabel Kepuasan Kerja Item-Total Statistics

\begin{tabular}{|l|r|r|r|r|}
\hline & $\begin{array}{c}\text { Scale } \\
\text { Mean if } \\
\text { Item } \\
\text { Deleted }\end{array}$ & $\begin{array}{c}\text { Scale } \\
\text { Variance if } \\
\text { Item } \\
\text { Deleted }\end{array}$ & $\begin{array}{c}\text { Corrected } \\
\text { Item-Total } \\
\text { Correlatio } \\
\text { n }\end{array}$ & $\begin{array}{c}\text { Cronbach' } \\
\text { s Alpha if } \\
\text { Item } \\
\text { Deleted }\end{array}$ \\
\hline KK1 & 7.80 & 1.586 & .619 & .729 \\
KK2 & 7.52 & 1.442 & .581 & .778 \\
KK3 & 7.61 & 1.480 & .705 & .640 \\
\hline
\end{tabular}

Sumber: SPSS 22, $2018(n=122)$
Tabel di atas menjelaskan hasil validitas dari variabel KK, yaitu Kepuasan Kerja. Pada tabel di atas dapat dilihat dari tabel Corrected Item-Total Correlation lebih besar di bandingkan $r$ table 0,176 . Maka dapat disimpulkan variabel Kepuasan Kerja Valid.

\section{Uji Reliabilitas}

Uji reliabilitas untuk mengukur suatu kestabilan dan konsistensi responden dalam menjawab hal yang berkaitan dengan pertanyaan dalam menjawab suatu variabel dan disusun dalam bentuk kuesioner. Uji reliabilitas menggunakan batasan Cronbach's Alpha yaitu 0,6. Jika hasil Cronbach's Alpha lebih dari 0,6 maka kuesioner dari variabel yang diajukan dinyatakan Reliabel.

\section{Uji Reliabiltas variabel Akuisisi pengetahuan}

Reliability Statistics

\begin{tabular}{|l|l|}
\hline Cronbach's Alpha & N of Items \\
\hline
\end{tabular} .790

\section{5}

Sumber: SPSS 22, $2018(n=122)$

Tabel diatas menjelaskan bahwa uji reliabilitas variabel akuisisi pengetahuan berdasakan tabel tersebut nilai Cronbach's Alpha menunjukan 0,790 . Dapat disimpulkan nilai tersebut lebih besar dari 0,6 sehingga variabel tersebut dinyatakan reliabel.

\section{Uji Reliabiltas variabel Berbagi Pengetahuan}

\section{Reliability Statistics}

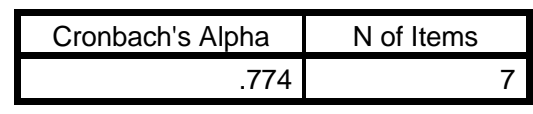

Sumber : SPSS 22, $2018(n=122)$

Tabel diatas menjelaskan bahwa uji reliabilitas variabel berbagi pengetahuan berdasakan tabel tersebut nilai Cronbach's 
Alpha menunjukan 0,774. Dapat disimpulkan nilai tersebut lebih besar dari 0,6 sehingga variabel tersebut dinyatakan reliabel.

\section{Uji Reliabiltas variabel Penciptaan Pengetahuan}

\section{Reliability Statistics}

\begin{tabular}{|l|l|}
\hline Cronbach's Alpha & $\mathrm{N}$ of Items \\
\hline
\end{tabular} .784

Sumber : SPSS 22, $2018(n=122)$

Tabel diatas menjelaskan bahwa uji reliabilitas variabel penciptaan pengetahuan berdasakan tabel tersebut nilai Cronbach's Alpha menunjukan 0,784. Dapat disimpulkan nilai tersebut lebih besar dari 0,6 sehingga variabel tersebut dinyatakan reliabel.

\section{Uji Reliabiltas variabel Kodifikasi Pengetahuan}

\section{Reliability Statistics}

\begin{tabular}{|l|l|}
\hline Cronbach's Alpha & N of Items \\
\hline
\end{tabular} .781

Sumber : SPSS 22, $2018(n=122)$

Tabel diatas menjelaskan bahwa uji reliabilitas variabel kodifikasi pengetahuan berdasakan tabel tersebut nilai Cronbach's Alpha menunjukan 0,781. Dapat disimpulkan nilai tersebut lebih besar dari 0,6 sehingga variabel tersebut dinyatakan reliabel.

\section{Uji Reliabiltas variabel
Pengetahuan
Reliability Statistics
\begin{tabular}{|r|r|}
\hline Cronbach's Alpha & N of Items \\
\hline .719 & 3 \\
\hline
\end{tabular}}

Sumber : SPSS 22, $2018(n=122)$

Tabel diatas menjelaskan bahwa uji reliabilitas variabel retensi pengetahuan berdasakan tabel tersebut nilai Cronbach's Alpha menunjukan 0,719. Dapat disimpulkan nilai tersebut lebih besar dari 0,6 sehingga variabel tersebut dinyatakan reliabel.

\section{Uji Asumsi Klasik \\ Uji Multikolinearitas}

Dari hasil dapat dilihat nilai VIF dari hasil uji asumsi klasik masih diantara 1-10 jadi tidak terjadi multikolinearitas antara variabel independen.

\section{Uji Normalitas}

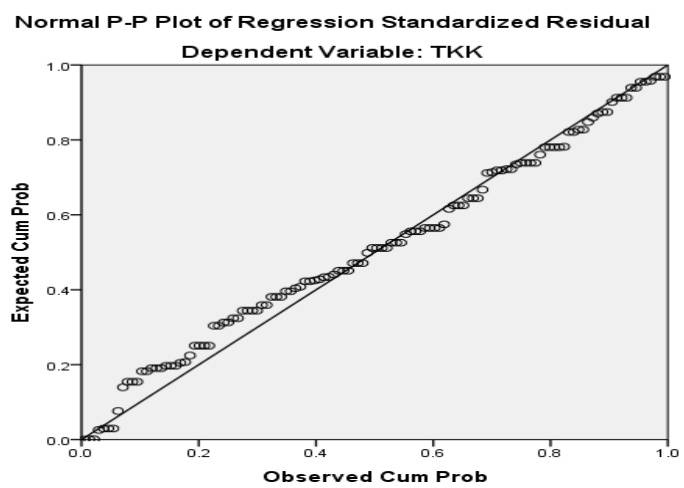

Sumber : SPSS 22, $2018(n=122)$

Gambar diatas menunjukan bahwa titik-titik tersebar disekitar garis diagonal (sumbu normal) dan mengikuti arah garis normal. Dari hasil gambar di atas dapat disimpulkan bahwa data dan model regresi berdistribusi normal dan memenuhi asumsi normalitas.

\section{Uji Heteroskedastisitas}

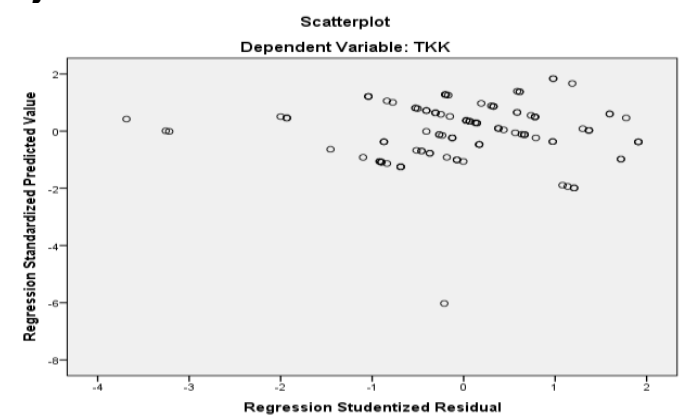

Sumber: SPSS 22, $2018(n=122)$

Jurnal IImu Sosial dan Humaniora | 217 
Dari gambar tersebut dapat dilihat bahwa tidak terjadi heteroskedastisitas sebab tidak ada pola yang jelas serta titik-titik menyebar di atas dan dibawah angka 0 pada sumbu y. sehingga dapat disimpulkan uji heteroskedastisitas terpenuhi.

\section{Analisis Regresi Linear Berganda Persamaan Regresi}

Berdasarkan data hasil, kolom Standardized Coefficients menunjukan nilai akuisisi pengetahuan sebesar $-0,195$, nilai berbagi pengetahuan sebesar 0,056, nilai penciptaan pengetahuan sebesar 0,151 , nilai kodifikasi pengetahuan sebesar 0,639 dan nilai retensi pengetahuan sebesar 0,075 . Jadi dapat diketahui bahwa persaamaan regresi adalah:

$\mathrm{Y}=\mathrm{a}+\mathrm{b} 1 \times 1+\mathrm{b} 2 \times 2+\mathrm{b} 3 \times 3+\mathrm{b} 4 \times 4+\mathrm{b} 5 \times 5+\mathrm{e}$ $Y=2,541+0,195 x_{1}+0,056 x_{2}+0,151 x_{3}+0,639 x_{4}$ $+0,075 x_{5}$

Koefisien Determinasi

Sumber : SPSS 22, $2018(n=122)$

Berdasarkan output model summary di atas, nilai $R$ square sebesar 0,616 atau $61,6 \%$.

Hal ini menunjukan bahwa variasi variabel independen yang digunakan dalam model (akuisisi pengetahuan, berbagi pengetahuan, penciptaan pengetahuan, kodifikasi pengetahuan, dan retensi pengetahuan) mampu menjelaskan sebesar $61,6 \%$ variasi variabel dependen (kepuasan kerja). Sedangkan sisanya sebesar $38,4 \%$ dipengaruhi atau dijelaskan oleh variabel lain yang tidak dimasukan dalam model penelitian ini.

\section{Uji t}

\section{Model Summary ${ }^{b}$}

\begin{tabular}{|l|l|l|l|l|}
\hline Model & $\mathrm{R}$ & $\begin{array}{l}\mathrm{R} \\
\text { Square }\end{array}$ & $\begin{array}{l}\text { Adjusted } \\
\text { R Square }\end{array}$ & $\begin{array}{l}\text { Std. Error } \\
\text { of the } \\
\text { Estimate }\end{array}$ \\
\hline 1 & $\begin{array}{l}.78 \\
5^{\mathrm{a}}\end{array}$ & .616 & .599 & 1.108 \\
\hline
\end{tabular}

a. Predictors: (Constant), TRP, TAP, TBP, TKP, TPP

b. Dependent Variable: TKK
H1: Pengujian Koefisien Regresi Variabel Akuisisi Pengetahuan Terhadap

\section{Kepuasan Kerja}

Merumuskan hipotesis :

$\mathrm{HO}$ : tidak terdapat pengaruh yang positif dan signifikan akuisisi pengetahuan terhadap kepuasan kerja karyawan pada PT. Indohotama Sejati.

$\mathrm{Ha}$ : terdapat pengaruh yang positif dan signifikan akuisisi pengetahuan terhadap kepuasan kerja karyawan pada PT. Indohotama Sejati.

Tingkat kepercayaan yang digunakan adalah 95\%, maka nilai $\alpha=0,05$.

\section{Kriteria pengujian :}

$\mathrm{HO}$ diterima dan $\mathrm{Ha}$ ditolak jika nilai sig > 0,05 .

HO ditolak dan Ha diterima jika nilai sig < 0,05 .

Hasil $0,002<0,05$.

\section{Kesimpulan :}

Karena nilai sig $<0,05$ maka $\mathrm{HO}$ ditolak dan Ha diterima, artinya terdapat pengaruh yang positif dan siginifikan akuisisi pengetahuan terhadap kepuasan kerja karyawan pada PT. Indohotama Sejati

\section{H2: Pengujian Koefisien Regresi Variabel Berbagi Pengetahuan Terhadap Kepuasan Kerja Merumuskan hipotesis :}

$\mathrm{HO}$ : tidak terdapat pengaruh yang positif dan signifikan berbagi pengetahuan terhadap kepuasan kerja karyawan pada PT. Indohotama Sejati.

$\mathrm{Ha}$ : terdapat pengaruh yang positif dan signifikan berbagi pengetahuan terhadap kepuasan kerja karyawan pada PT. Indohotama Sejati.

Tingkat kepercayaan yang digunakan adalah 95\%, maka nilai $\alpha=0,05$.

\section{Kriteria pengujian :}

$\mathrm{HO}$ diterima dan $\mathrm{Ha}$ ditolak jika nilai sig > 0,05 .

HO ditolak dan $\mathrm{Ha}$ diterima jika nilai sig < 0,05 .

Hasil 0,467 >0,05 


\section{Kesimpulan :}

Karena nilai sig > 0,05 maka HO diterima dan $\mathrm{Ha}$ ditolak, artinya tidak terdapat pengaruh yang positif dan siginifikan berbagi pengetahuan terhadap kepuasan kerja karyawan pada PT. Indohotama Sejati.

\section{H3: Pengujian Koefisien Regresi Variabel Penciptaan Pengetahuan Terhadap Kepuasan Kerja \\ Merumuskan hipotesis :}

$\mathrm{HO}$ : tidak terdapat pengaruh yang positif dan signifikan penciptaan pengetahuan terhadap kepuasan kerja karyawan pada PT. Indohotama Sejati.

$\mathrm{Ha}$ : terdapat pengaruh yang positif dan signifikan penciptaan pengetahuan terhadap kepuasan kerja karyawan pada PT. Indohotama Sejati.

Tingkat kepercayaan yang digunakan adalah $95 \%$, maka nilai $\alpha=0,05$.

Kriteria pengujian :

HO diterima dan Ha ditolak jika nilai sig > 0,05 .

HO ditolak dan Ha diterima jika nilai sig < 0,05 .

Hasil 0,057>0,05

Kesimpulan :

Karena nilai sig > 0,05 maka $\mathrm{HO}$ diterima dan $\mathrm{Ha}$ ditolak, artinya tidak terdapat pengaruh yang positif dan siginifikan penciptaan pengetahuan terhadap kepuasan kerja karyawan pada PT. Indohotama Sejati.

\section{H4: Pengujian Koefisien Regresi Variabel Kodifikasi Pengetahuan Terhadap Kepuasan Kerja \\ Merumuskan hipotesis :}

$\mathrm{HO}$ : tidak terdapat pengaruh yang positif dan signifikan kodifikasi pengetahuan terhadap kepuasan kerja karyawan pada PT. Indohotama Sejati.

$\mathrm{Ha}$ : terdapat pengaruh yang positif dan signifikan kodifikasi pengetahuan terhadap kepuasan kerja karyawan pada PT. Indohotama Sejati.

Tingkat kepercayaan yang digunakan adalah $95 \%$, maka nilai $\alpha=0,05$.

\section{Kriteria pengujian :}

$\mathrm{HO}$ diterima dan $\mathrm{Ha}$ ditolak jika nilai sig > 0,05 .

H0 ditolak dan Ha diterima jika nilai sig < 0,05 .

Hasil $0,000<0,05$

\section{Kesimpulan :}

Karena nilai sig $<0,05$ maka $\mathrm{HO}$ ditolak dan Ha diterima, artinya terdapat pengaruh yang positif dan siginifikan kodifikasi pengetahuan terhadap kepuasan kerja karyawan pada PT. Indohotama Sejati.

\section{H5: Pengujian Koefisien Regresi Variabel Retensi Pengetahuan Terhadap Kepuasan Kerja Merumuskan hipotesis :}

$\mathrm{HO}$ : tidak terdapat pengaruh yang positif dan signifikan retensi pengetahuan terhadap kepuasan kerja karyawan pada PT. Indohotama Sejati.

Ha: terdapat pengaruh yang positif dan signifikan retensi pengetahuan terhadap kepuasan kerja karyawan pada PT. Indohotama Sejati.

Tingkat kepercayaan yang digunakan adalah $95 \%$, maka nilai $\alpha=0,05$.

\section{Kriteria pengujian :}

$\mathrm{HO}$ diterima dan $\mathrm{Ha}$ ditolak jika nilai sig > 0,05 .

$\mathrm{HO}$ ditolak dan Ha diterima jika nilai sig < 0,05 .

Hasil 0,287 >0,05

\section{Kesimpulan :}

Karena nilai sig $>0,05$ maka $\mathrm{HO}$ diterima dan $\mathrm{Ha}$ ditolak, artinya tidak terdapat pengaruh yang positif dan siginifikan retensi pengetahuan terhadap kepuasan kerja karyawan pada PT. Indohotama Sejati. 


\section{Uji F}

ANOVA $^{\mathrm{a}}$

\begin{tabular}{|l|l|l|l|l|l|}
\hline Model & $\begin{array}{l}\text { Sum of } \\
\text { Squares }\end{array}$ & df & $\begin{array}{l}\text { Mean } \\
\text { Square }\end{array}$ & $\mathrm{F}$ & Sig. \\
\hline $\begin{array}{l}\text { 1 Regressio } \\
\mathrm{n}\end{array}$ & 227.950 & 5 & 45.590 & 37.152 & $.000^{\mathrm{b}}$ \\
$\begin{array}{l}\text { Residual } \\
\text { Total }\end{array}$ & 142.345 & 116 & 1.227 & & \\
\hline
\end{tabular}

a. Dependent Variable: TKK

b. Predictors: (Constant), TRP, TAP, TBP, TKP, TPP

Sumber : SPSS 22, $2018(n=122)$

Dari tabel di atas, diketahui nilai signifikasi sebesar 0,000. Karena nilai signifikansi $0,000<0,05$. Dapat disimpulkan terdapat pengaruh yang positif dan signifikan bahwa Akuisisi Pengetahuan (X1), Berbagi Pengetahuan (X2), Penciptaan Pengetahuan (X3), Kodifikasi Pengetahuan (X4), Retensi Pengetahuan (X5) berpengaruh secara simultan terhadap Kepuasan Kerja (Y).

\section{SIMPULAN DAN SARAN}

Berdasarkan hasil analisis yang telah dilakukan dengan memperhatikan berbagai hal, maka peneliti dapat menyimpulkan bahwa hasil pengujian yang telah dilakukan yang mengenai pengaruh akuisisi pengetahuan terhadap kepuasan kerja membuktikan terdapat pengaruh yang siginifikan dengan hasil perhitungan program SPSS nilai signifikan 0,002 <0,05. $\mathrm{Hal}$ ini menunjukan terdapat pengaruh yang positif dan siginifikan akuisisi pengetahuan terhadap kepuasan kerja karyawan pada PT. Indohotama Sejati. Hasil pengujian yang telah dilakukan yang mengenai pengaruh berbagi pengetahuan terhadap kepuasan kerja membuktikan tidak terdapat pengaruh yang siginifikan dengan hasil perhitungan program SPSS nilai signifikan 0,467 >0,05. Hal ini menunjukan tidak terdapat pengaruh yang positif dan siginifikan akuisisi pengetahuan terhadap kepuasan kerja karyawan pada PT. Indohotama Sejati. Hasil pengujian yang telah dilakukan yang mengenai pengaruh penciptaan pengetahuan terhadap kepuasan kerja membuktikan tidak terdapat pengaruh yang siginifikan dengan hasil perhitungan program SPSS nilai signifikan 0,057 >0,05. Hal ini menunjukan tidak terdapat pengaruh yang positif dan siginifikan penciptaan pengetahuan terhadap kepuasan kerja karyawan pada PT. Indohotama Sejati. Hasil pengujian yang telah dilakukan yang mengenai pengaruh kodifikasi pengetahuan terhadap kepuasan kerja membuktikan terdapat pengaruh yang siginifikan dengan hasil perhitungan program SPSS nilai signifikan 0,000 0,05. Hal ini menunjukan terdapat pengaruh yang positif dan siginifikan kodifikasi pengetahuan terhadap kepuasan kerja karyawan pada PT. Indohotama Sejati. Hasil pengujian yang telah dilakukan yang mengenai pengaruh retensi pengetahuan terhadap kepuasan kerja membuktikan tidak terdapat pengaruh yang siginifikan dengan hasil perhitungan program SPSS nilai signifikan 0,287 >0,05. Hal ini menunjukan tidak terdapat pengaruh yang positif dan siginifikan retensi pengetahuan terhadap kepuasan kerja karyawan pada PT. Indohotama Sejati. Hasil pengujian yang telah dilakukan yang mengenai pengaruh Akuisisi Pengetahuan, Berbagi Pengetahuan, Penciptaan Pengetahuan, Kodifikasi Pengetahuan, Retensi Pengetahuan terhadap Kepuasan Kerja. dengan hasil perhitungan program SPSS nilai signifikansi $0,000<0,05$. Dapat disimpulkan terdapat pengaruh yang positif dan signifikan bahwa Akuisisi Pengetahuan (X1), Berbagi Pengetahuan (X2), Penciptaan Pengetahuan (X3), kodifikasi pengetahuan (X4), Retensi Pengetahuan (X5) berpengaruh secara simultan terhadap Kepuasan Kerja (Y).

\section{DAFTAR PUSTAKA}

Adiwinata, I., \& Sutanto, E. M. (2014). Pengaruh Kepuasan Kerja Dan Motivasi Kerja Terhadap Produktivitas Kerja Karyawan Cv. Intaf Lumajang, 2(1), 12. 
Arikunto, S. (2014). Prosedur Penelitian. Jakarta: Rineka Cipta.

Ciptagustia, A. (2015). Pengaruh Manajemen Pengetahuan Melalui Knowledge Worker Terhadap Efektivitas Organisasi Program Studi S1 Di Universitas Pendidikan Indonesia. Pengaruh Manajemen Pengetahuan Melalui Knowledge Worker Terhadap Efektivitas Organisasi Program Studi S1 Di Universitas Pendidikan Indonesia (Survei.

Fauzi. (2019). Metode Penelitian Kuantitatif Dan Kualitatif. Bandung: Alfabeta.

Ghozali, I. (2015). Aplikasi Analisis Multivariate Dengan Program Ibm Spss 21 Edisi 7. Semarang: Universitas Diponegoro.

Kianto, A., Vanhala, M., \& Heilmann, P. (2016). The Impact of Knowledge Management on Job Satisfaction. Journal of Knowledge Management, 20(4), 621-636. Https://Doi.Org/10.1108/Jkm-10-20150398

Mahadianto, M. Y., \& Setiawan, A. (2013). Analisis Parametik Dependensi Dengan Program Spss. Jakarta: Rajawali Pers.

Potale, R., \& Uhing, Y. (2015). Pengaruh Kompensasi Dan Stres Kerja Terhadap Kepuasan Kerja Karyawan Pada Pt. Bank Sulut Cabang Utama Manado. Pengaruh Kompensasi Dan Stres Kerja Terhadap Kepuasan Kerja Karyawan Pada Pt. Bank Sulut Cabang Utama Manado, 633(1), 63-73.

Priyono. (2013). Metode Penelitian Kuantitatif. Surabaya: Zifatama Publishing.

Shabrina, V., \& Silvianita, A. (2015). Factors Analysis on Knowledge Sharing at Telkom Economic and Business School (Tebs) Telkom University Bandung. Factors Analysis on Knowledge Sharing at Telkom Economic and Business School (Tebs) Telkom University Bandung, 169(August 2014), 198-206. Https://Doi.Org/10.1016/J.Sbspro.2015. 01.303
Sugiyono. (2014). Metode Penelitian Kuantitatif Kualitatif Dan R\&D. Bandung: Alfabeta.

Sujarweni, V. W. (2015). Spss Untuk Penelitian. Yogyakarta: Pustaka Baru Press.

Trivellas, P., Akrivouli, Z., Tsifora, E., \& Tsoutsa, P. (2015). The Impact of Knowledge Sharing Culture on Job Satisfaction in Accounting Firms. The Mediating Effect of General Competencies. The Impact of Knowledge Sharing Culture on Job Satisfaction in Accounting Firms. The Mediating Effect of General Competencies Panagiotis, 19(15), 238247. Https://Doi.Org/10.1016/S22125671(15)00025-8

Tsirikas, A. N., \& Katsaros, K. K. (2014). Linking Knowledge Management, Job Satisfaction and Productivity in The Greek Public Sector. International Journal of Knowledge Management Studies, 5(3-4), 244-264. Https://Doi.Org/10.1504/ljkms.2014.067 219

Waluyo, R. (2017). Pemodelan System Dynamics Untuk Aliran Knowledge Management Di Perusahaan Konstruksi: Sebuah Studi Kasus. Pemodelan System Dynamics Untuk Aliran Knowledge Management Di Perusahaan Konstruksi: Sebuah Studi Kasus, (2004), 26-27. 